\title{
KARAKTERISTIK PEMENUHAN KEBUTUHAN SPIRITUALITAS PADA PASIEN YANG DIRAWAT DI RUANG ICU
}

\author{
Dina Rasmita ${ }^{1}$, Siti Zahara Nasution ${ }^{2,}$ Iwan Rusdi $^{3}$ \\ ${ }^{1,2,3}$ Fakultas Keperawatan, Universitas Sumatera Utara \\ Email: dinarasmita@gmail.com
}

\begin{abstract}
Spirituality was important when an individual is sick. Patients ICU with spiritual distress, so they need to fulfill their spiritual needs. Fulfillment spirituality needs can be done by nurses and families. The purpose was to determine how nurses and patients' families fulfilling the spiritual needs of ICU patients. This study was a descriptive design. Nurses who work in the Intensive Care Unit (ICU) and families of ICU patients were the populations of this study. The sample size was determined using a purposive sampling technique, which 30 ICU nurses and 32 ICU patient families. The data collection tool used a questionnaire. Data analysis used univariate analysis with frequency distribution. The results show that $66.7 \%$ of the nurses fulfilled the spiritual needs of patients with a good category, $53.1 \%$ of the patients' families were a not good category in fulfilling ICU patient's spiritual needs. This study concludes that the fulfillment of spirituality needs in ICU patients has been optimally implemented by nurses but has not been optimally implemented by the family. Fulfillment spirituality needs in ICU patients by nurses with good categories so nurses are improved it through training and nurses can increase the family role.
\end{abstract}

Keywords: spiritual, ICU, ICU patient

\section{PENDAHULUAN}

Pasien ICU (Intensive Care Unit) memerlukan perawatan secara intensif sehingga sangat bergantung pada orang lain dalam pemenuhan segala kebutuhannya. Kondisi pasien ICU banyak menimbulkan dampak psikologis pada pasien dan keluarga. Dampak dari kondisi tersebut menimbulkan ketidakberdayaan dan keputusaan dalam proses penyembuhan yang disebut dengan distress spiritual (Laili et al., 2019). Distress spiritual adalah kondisi pasien ICU merasa tidak berdaya, pasien merasa bersalah pada dirinya, tidak berharga dan hidupnya tidak berarti.
Distress spiritual yang dialami oleh pasien menyebabkan penurunan kekebalan tubuh yang memperberat kondisinya (Nurhanif, Purnawan, \& Sobihin, 2020).

Penelitian Hupcey tahun 2000 menunjukkan bahwa 45 pasien yang dirawat di ICU selama tiga hari mengalami distress spiritual. Hasil penelitian Rosita tahun 2014 juga menyebutkan bahwa pasien yang dirawaat di ICU sering mengalami cemas, gelisah dan mengalami distress spiritual (Wardhani, 2017).

Spitualitas merupakan bagian yang penting pada kehidupan individu dan 
menjadi sumber kekuatan individu khususunya ketika individu menghadapi penyakit (Wardhani, 2017). Ketika sakit energi dan spiritualitas seseorang menurun, sehingga kebutuhan spiritual pasien harus dipenuhi (Hardianto, 2017). Manusia adalah mahluk biopsikososial dan spiritual sehingga dalam keadaan sehat dan sakit, semua unsur harus terpenuhi. Penelitian yang dilakukan oleh Hodge dan Horvath (2011) tentang kebutuhan spiritual pasien menunjukkan bahwa kebutuhan spiritual pasien adalah kebutuhan makna, tujuan dan harapan dalam hidup, hubungan dengan Tuhan seperti melaksanakan kewajiban agama, hubungan dengan sesama dan hubungan dengan perawat.

Berdasarkan studi pendahuluan pada perawat dan keluarga pasien di ruang ICU RSUP Haji Adam Malik Medan bahwa 20 orang perawat dari $30(66,7 \%)$ menyebutkan bahwa pemenuhan kebutuhan spiritualitas pasien berkaitan dengan Tuhan seperti praktik agama, beribadah dan 17 orang perawat dari 30 $(56,7 \%)$ menyebutkan bahwa pemenuhan kebutuhan spiritualitas pasien diserahkan kepada rohaniawan di rumah sakit, sedangkan pemenuhan kebutuhan spiritualitas menurut keluarga bahwa pemenuhan kebutuhan spiritualitas yaitu hubungan dengan Tuhan seperti praktik keagamaan.
Beberapa penelitian menyebutkan bahwa perawat di ICU jarang melakukan pemenuhan kebutuhan spiritual pada pasien ICU. Perawat ICU lebih fokus pada pemenuhan kebutuhan fisiologis pasien (Chrash et al., 2011). Beberapa penelitian juga menyebutkan bahwa perawat ingin melakukan pemenuhan kebutuhan spiritual pada pasien, tetapi perawat tidak mengetahui cara pemenuhan kebutuhan spiritualitas pada pasien dan merasa kurang terampil dalam pemenuhan kebutuhan spiritualitas pada pasien.

Perawat dan keluarga berperan dalam pemenuhan kebutuhan spiritualitas pasien. Perawat dapat memberikan pelayanan secara holistik walaupun dengan beban kerja yang tinggi. Pelayanan holistik bisa dilakukan oleh perawat tidak hanya berfokus pada kebutuhan dasar pasien, tetapi pemenuhan kebutuhan spiritual pasien (Hardianto, 2017). Perawat yang bekerja di ICU lebih memperhatikan perawatan fisiologis pasien, tetapi perawat jarang memperhatikan kebutuhan psikologis dan spiritual pasien. Pemenuhan kebutuhan spiritual dapat dilakukan oleh perawat dan keluarga (Balboni et al., 2013). Keluarga mempunyai peran dalam pemenuhan kebutuhan spiritual karena keluarga memiliki ikatan emosional dan selalu berinteraksi dengan pasien. Dukungan keluarga 
dapat membantu permasalahan yang sedang terjadi pada pasien seperti masalah pemenuhan kebutuhan spiritual dan dukungan tersebut berdampak positif pada pasien selama menghadapi sakit (Susilawati, 2014a) Berdasarkan latar belakang tersebut, peneliti ingin mengetahui pelaksanaan pemenuhan kebutuhan spiritualitas pada pasien ICU yang dilakukan oleh perawat dan keluarga.

\section{METODE}

Desain penelitian ini adalah desain penelitian deskriptif. Populasi penelitian ini yaitu seluruh perawat yang bekerja di ruang ICU dan keluarga dari pasien yang dirawat di ruang ICU. Penentuan besar sampel menggunakan teknik purposive sampling dengan kriteria inklusi perawat yaitu perawat pelaksana di ruang ICU Dewasa dan Pasca Bedah, perawat bekerja $\geq 2$ tahun, sedangkan kriteria inklusi keluarga yaitu keluarga dari pasien yang dirawat di ruang ICU Dewasa dan Pasca Bedah dengan lama perawatan $\geq 3$ hari, keluarga yang paling sering menjenguk pasien, dapat membaca dan menulis, dan dapat berbahasa Indonesia. Besar sampel ditentukan dengan rumus power analize yaitu dengan derajat ketepatan ( $\alpha=$ level of significance) sebesar 0,05, effect size sebesar 0,70, dan power sebesar 0,80. Sampel penelitian adalah 30 orang perawat ICU dan 32 orang keluarga pasien ICU.

Penelitian ini menggunakan instrumen yaitu kuesioner berisi data demografi responden dan pemenuhan kebutuhan spiritualitas pada pasien yang dirawat di ruang ICU yang dilakukan oleh perawat dan keluarga. Kuesioner pemenuhan kebutuhan spiritualitas pada pasien ICU dibuat oleh peneliti sendiri dengan berpedoman pada literatur Galek, Flannelly, Vane (2005), Taylor, Lilis, Le Mone (1997), dan Burkhardt (1993 dalam Kozier B, Erb G, Berman, 2004). Instrumen telah dilakukan uji validitas isi dan uji reabilitas dengan alpha cronbach. Hasil uji reabilitas kuesioner perawat yaitu 0,753 dan hasil uji reabilitas kuesioner keluarga yaitu 0,746. Data hasil penelitian dianalisis dengan distribusi frekuensi.

\section{HASIL DAN PEMBAHASAN}

Hasil penelitian menunjukkan bahwa sebagian besar perawat berusia antara 21-30 tahun yaitu 12(40\%) dan 31-40 tahun yaitu 12 (40\%), mayoritas berjenis kelamin perempuan yaitu 24 (80\%), beragama Kristen yaitu 17 (56,7\%), berpendidikan diploma yaitu $24(80 \%)$, bekerja sebagai perawat ICU selama 2-4 tahun yaitu 14 (46,6\%). Distribusi karakteristik demografi perawat dapat dilihat pada Tabel 1. 
Tabel 1. Karakteristik Data Demografi Perawat

\begin{tabular}{|c|c|c|}
\hline Karakteristik & $f$ & $\%$ \\
\hline \multicolumn{3}{|l|}{ Usia (tahun) } \\
\hline $21-30$ & 12 & 40 \\
\hline $31-40$ & 12 & 40 \\
\hline $41-50$ & 6 & 20 \\
\hline Total & 30 & 100 \\
\hline \multicolumn{3}{|l|}{ Jenis kelamin } \\
\hline Laki-laki & 6 & 20 \\
\hline Perempuan & 24 & 80 \\
\hline Total & 30 & 100 \\
\hline \multicolumn{3}{|l|}{ Agama } \\
\hline Islam & 13 & 43,3 \\
\hline Kristen & 17 & 56,7 \\
\hline $\begin{array}{r}\text { Total } \\
\end{array}$ & 30 & 100 \\
\hline \multicolumn{3}{|l|}{ Tingkat Pendidikan } \\
\hline SPK & 2 & 6,7 \\
\hline SMU & 24 & 80 \\
\hline S1 Keperawatan & 4 & 13,3 \\
\hline Total & 30 & 100 \\
\hline
\end{tabular}

Karakteristik demografi keluarga pasien menunjukkan bahwa mayoritas perempuan sebanyak $18 \quad(56,3 \%)$, berusia antara 41-60 tahun sebanyak 17 $(53,1 \%)$, beragama Islam sebanyak 21
$(65,6 \%)$, tingkat pendidikan SMA sebanyak 20 (20\%), lama perawatan pasien >3 hari sebanyak $17(53,1 \%)$, hubungan keluarga dengan klien sebagai ibu sebanyak 12 (37,5\%).

Tabel 2. Karakteristik Demografi Keluarga Pasien

\begin{tabular}{|c|c|c|}
\hline Karakteristik & $f$ & $\%$ \\
\hline \multicolumn{3}{|l|}{ Usia (tahun) } \\
\hline $21-30$ & 14 & 43,8 \\
\hline $31-40$ & 17 & 53,1 \\
\hline $41-50$ & 1 & 3,1 \\
\hline Total & 30 & 100 \\
\hline \multicolumn{3}{|l|}{ Jenis kelamin } \\
\hline Laki-laki & 14 & 43,3 \\
\hline Perempuan & 18 & 56,7 \\
\hline Total & 30 & 100 \\
\hline \multicolumn{3}{|l|}{ Agama } \\
\hline Islam & 21 & 65,6 \\
\hline Kristen & 11 & 34,4 \\
\hline Total & 30 & 100 \\
\hline \multicolumn{3}{|l|}{ Tingkat Pendidikan } \\
\hline $\mathrm{SD}$ & 4 & 12,5 \\
\hline SMP & 3 & 9,4 \\
\hline SMU & 20 & 62,4 \\
\hline Diploma (DIII) & 2 & 6,3 \\
\hline Sarjana & 3 & 9,4 \\
\hline Total & 30 & 100 \\
\hline
\end{tabular}




\begin{tabular}{|c|c|c|}
\hline Hubungan keluarga den & & \\
\hline Ayah & 9 & 28,9 \\
\hline Ibu & 13 & 40,6 \\
\hline Anak & 5 & 15,6 \\
\hline Suami & 5 & 15,6 \\
\hline Total & 30 & 100 \\
\hline Lama perawatan pasien & & \\
\hline 3 hari & 15 & 46,9 \\
\hline$>3$ hari & 17 & 53,1 \\
\hline Total & 30 & 100 \\
\hline
\end{tabular}

Pemenuhan kebutuhan spiritualitas pasien yang dirawat di ruang ICU yang dilakukan oleh perawat dalam kategori baik, sedangkan oleh keluarga dalam kategori kurang baik.

\section{Tabel 3. Karaktersitik Pemenuhan Kebutuhan Spiritualitas Pasien yang Dirawat di Ruang ICU}

\begin{tabular}{|c|c|c|}
\hline Karaktersitik & $f$ & $\%$ \\
\hline \multicolumn{3}{|c|}{ Pemenuhan Kebutuhan Spiritualitas oleh } \\
\hline \multicolumn{3}{|c|}{ Perawat } \\
\hline Baik & 20 & 66,7 \\
\hline Kurang Baik & 10 & 33,3 \\
\hline Total & 30 & 100 \\
\hline \multicolumn{3}{|c|}{ Pemenuhan Kebutuhan Spritualitas oleh } \\
\hline \multicolumn{3}{|c|}{ Keluarga } \\
\hline Baik & 15 & 46,9 \\
\hline Kurang Baik & 17 & 53,1 \\
\hline Total & 30 & 100 \\
\hline
\end{tabular}

\section{Pembahasan}

Pemenuhan kebutuhan spiritualitas pada pasien yang dirawat di ruang ICU dilakukan oleh $20 \quad(66,7 \%)$ perawat berada dalam kategori baik dan 10 $(33,3 \%)$ perawat kurang baik dalam pemenuhan kebutuhan spiritualitas pasien yang dirawat di ICU. Hal ini sesuai dengan Hardianto (2017) bahwa perawat dapat memberikan pelayanan yang komprehensif dan prima walaupun dengan beban kerja yang tinggi. Pelayanan komprehensif dan prima bisa dilakukan oleh perawat tidak hanya berfokus pada kebutuhan dasar pasien, tetapi pemenuhan kebutuhan spiritual pasien. Hal ini juga didukung oleh pernyataan Kristen, et al (2014)bahwa perawat harus mampu melakukan pemenuhan kebutuhan spiritual pasien karena pemenuhan kebutuhan spiritual merupakan standar kinerja perawat. Hasil penelitian menunjukkan bahwa sebagian besar perawat berusia dewasa dini sebanyak 24 orang (80\%). Kelompok usia dewasa dini seebagai 
faktor pendukung dalam memberikan pelayanan keperawatan yang baik. Hal ini sesuai dengan penelitian Kumajas et al. (2014) menyatakan bahwa karakteristik seorang perawat berdasarkan umur sangat berpengaruh terhadap kinerja bahwa semakin tua umur perawat maka semakin berpengalaman dalam pekerjaan. Umur yang semakin bertambah maka kemampuan seseorang semakin baik dalam mengambil keputusan, berpikir, mengatur emosi, dan bertoleransi terhadap orang lain, sehingga kualitas kinerja meningkat.

$$
\text { Penelitian Romadhoni }
$$

mendukung hasil penelitian ini bahwa pemenuhan kebutuhan spiritualitas yang dilakukan oleh perawat di antaranya yaitu membimbing pasien yang sadar untuk berdoa saat takut dan cemas, pada pasien tidak koma memfasilitasi pasien untuk beribadah, memfasilitasi rohaniawan untuk pasien, memperhatikan dan mendengarkan keluhan pasien, serta mengkaji hal yang dibutuhkan pasien, perawat sering mendatangkan keluarga atau orang terdekat klien ketika dibutuhkan, perawat sering menenangkan pasien yang kondisinya tidak koma untuk menerima kondisinya, perawat selalu berbicara dengan pasien ketika melakukan perawatan, perawat selalu memberi dukungan kepada pasien dalam menghadapi kondisinya dan perawat menjaga ruangan ICU bersih dan tidak ribut. Penelitian Romadhoni (2013) menyatakan bahwa peran perawat dalam pemenuhan kebutuhan spiritualitas pasien yaitu perawat selalu ada jika pasien membutuhkan sesuatu, menghadirkan orang terdekat pasien seperti keluarga, memberitahu kondisi pasien, memberi motivasi, mengajarkan dan membimbing berdoa pada pasien, mengingatkan dan mempersiapkan alat ibadah, memfasilitasi kehadiran rohaniawan dan berkolaborasi dengan keluarga pasien dalam pemenuhan kebutuhan spiritualitas pasien. Hasil penelitian Nurhanif dan Purnawani (2020) menyebutkan bahwa perawat melakukan pemenuhan kebutuhan spiritualitas pada pasien ICU seperti perawat selalu merespon kebutuhan pasien, menghadirkan orang terdekat pasien, memberi tahu kondisi pasien, memberi motivasi, mengajarkan dan membimbing pasien untuk berdoa, mengingatkan dan mempersiapkan alat ibadah untuk pasien.

Namun, sebanyak 10 perawat kurang baik dalam pelaksanaan pemenuhan kebutuhan spiritualitas pada pasien yang dirawat di ruang ICU. Hal ini sesuai dengan pernyataan Wardhani (2017) yang menyatakan bahwa pemenuhan kebutuhan spiritual merupakan tindakan mandiri perawat 
dalam memberikan asuhan keperawatan secara holistik, tetapi pemenuhan kebutuhan spiritual pasien oleh perawat masih belum optimal. Hasil penelitian Romadoni (2013) bahwa perawat kurang berperan dalam pemenuhan kebutuhan spiritual karena perawat menganggap pemenuhan kebutuhan spiritual pasien bukan prioritas dalam asuhan keperawatan, kesibukan di ruang ICU, perbedaan agama, menganggap agama adalah hal privasi, dan kurang memahami tentang konsep spiritual. Hasil penelitian ini juga menunjukkan sebagian besar perawat beragama Kristen sebanyak 17 orang $(56,7 \%)$, sedangkan pasien sebagian besar beragama Islam yaitu 21 orang $(65,6 \%)$.

Penelitian Hardianto (2017) bahwa salah satu hambatan perawat dalam pemenuhan kebutuhan spiritual pasien yaitu perawat merawat pasien yang berbeda agama, sehingga perawat bingung dan ragu karena perbedaan agama dan budaya dengan pasien. Perawat merasa tidak nyaman karena takut salah dan menganggap spiritual merupakan hak pribadi pasien. Hal ini juga didukung penelitian Hardianto (2017) menyatakan bahwa beban kerja yang cukup tinggi menyebabkan perawat tidak memiliki waktu untuk melakukan pemenuhan kebutuhan spiritual pasien.
Pemenuhan kebutuhan spiritualitas pada pasien yang dirawat di ruang ICU oleh keluarga sebagian besar keluarga pasien melakukannya kurang baik. Menurut Perry dan Potter (2012) menyatakan bahwa semakin lama seseorang menghadapi stressor maka individu dapat beradaptasi dengan stressor yang dialaminya. Hal ini didukung hasil penelitian menunjukkan bahwa lama perawatan pasien sebagian besar $\geq 3$ hari yaitu 17 (46,9\%), sehingga stressor yang dialami oleh keluarga lebih panjang dan berpengaruh pada pemenuhan kebutuhan spiritualitas keluarga yang dirawat. Hal ini juga didukung dengan asumsi peneliti bahwa adanya peraturan khusus antara keluarga dengan pasien dan jam kunjungan keluarga pasien yang terbatas sehingga pemenuhan kebutuhan spiritualitas oleh keluarga kurang optimal. Hasil penelitian menunjukkan bahwa sebagian besar keluarga memiliki tingkat pendidikan SMA. Menurut Hamid (2009) yang menyatakan bahwa salah satu faktor yang dapat mempengaruhi spiritual seseorang adalah usia. Semakin tinggi tingkat pendidikan seseorang semakin mudah menerima informasi dan semakin baik pengetahuan yang dimiliki.

Pemenuhan kebutuhan spiritualitas oleh keluarga dalam kategori baik. Keluarga merupakan sistem pendukung 
dalam pemulihan pasien selama menjalani perawatan di ruang intensif. Keluarga perlu dilibatkan dalam perawatan pasien (Garrouste-Orgeas et al., 2010; Rahmawati, 2015). Hal ini didukung oleh pernyataan Perry dan Potter (2012) bahwa ketika salah satu anggota keluarga sakit maka keluarga berperan dalam mengambil keputusan, memberi dukungan kepada anggota keluarga yang sakit, dan melakukan koping terhadap perubahan dan tantangan hidup sehari-hari. Hal ini juga didukung penelitian Makmun et al. (2019) yang menyatakan bahwa keluarga berkeinginan untuk membantu memenuhi kebutuhan pasien selama berada di samping pasien seperti memberi makan, minum dan apa yang dibutuhkan pasien dengan sepenuh hati, memijat serta mendo'akan pasien. Hasil penelitian juga menunjukkan bahwa $53,1 \%$ keluarga pasien berada pada usia dewasa tengah.

Hal ini sesuai pernyataan Friedman (2013) menyebutkan bahwa usia adalah faktor utama yang berpengaruh pada struktur peran dalam memberikan asuhan keperawatan keluarga, sehingga semakin bertambah usia seseorang maka dukungan keluarga semakin turun karena semakin dewasa seseorang atau semakin bertambah usia seseorang maka individu semakin berkurang untuk bersosialisasi. Hasil penelitian ini menunjukkan pemenuhan kebutuhan spiritualitas sering dilakukan oleh keluarga yaitu berdoa. Menurut Friedman (2013) menyatakan bahwa Tuhan, doa, dan iman adalah cara untuk mengatasi suatu penyakit. Hal ini sesuai dengan pernyataan Laili et al. (2019) bahwa dukungan keluarga dalam pemenuhan kebutuhan spiritual yaitu berdoa, meyakinkan pasien dan memotivasi pasien, mengajak rohaniawan untuk membimbing spiritual pasien sehingga berdampak positif pada psikologis, kesejahteraan fisik pasien sehingga pasien dapat menerima kondisinya, nyaman dan memberikan rasa damai dalam menuju kematian. Hal ini didukung oleh Susilawati (2014) bahwa berdoa dapat membantu seseorang dalam mencari jati diri sehingga membantu kehidupan seseorang yang berhubungan dengan TuhanNya.

\section{KESIMPULAN DAN SARAN}

Pemenuhan kebutuhan spiritualitas pada pasien ICU yang dilakukan oleh perawat sudah baik, namun pemenuhan kebutuhan spiritualitas pada pasien ICU yang dilakukan oleh keluarga kurang baik. Perawat meningkatkan pengetahuan terkait pemenuhan kebutuhan spiritualitas pada pasien melalui pelatihan. Perawat perlu meingkatkan keterlibatan keluarga 
dalam pemenuhan kebutuhan spiritualitas pada pasien ICU.

\section{DAFTAR PUSTAKA}

Balboni, T. A., Balboni, M., Enzinger, A. C., Gallivan, K., Paulk, M. E., Wright, A., Steinhauser, K., VanderWeele, T. J., \& Prigerson, H. G. (2013). Provision of spiritual support to patients with advanced cancer by religious communities and associations with medical care at the end of life. JAMA Internal Medicine, 173(12), 1109-1117. https://doi.org/10.1001/jamainternme d.2013.903

Chrash, M., Mulich, B., \& Patton, C. M. (2011). The APN role in holistic assessment and integration of spiritual assessment for advance care planning. Journal of the American Academy of Nurse Practitioners, 23(10), 530-536. https://doi.org/10.1111/j.17457599.2011.00644.x

Friedman, M. (2013). Buku Ajar Keperawatan Keluarga: Riset, Teori Dan Praktik. EGC.

Garrouste-Orgeas, M., Willems, V., Timsit, J. F., Diaw, F., Brochon, S., Vesin, A., Philippart, F., Tabah, A., Coquet, I., Bruel, C., Moulard, M. L., Carlet, J., \& Misset, B. (2010). Opinions of families, staff, and patients about family participation in care in intensive care units. Journal of Critical Care, 25(4), 634-640. https://doi.org/10.1016/j.jcrc.2010.03 .001

Hamid. (2009). Bunga Rampai Asuhan Keperawatan Kesehatan Jiwa. EGC.

Hardianto. (2017). Pemenuhan kebutuhan spiritual pasien di ruang ICU Rumah Sakit Umum Daerah Haji Makassar [Universitas Islam Negeri Alauddin Makassar]. http://repositori.uinalauddin.ac.id/387 2/

Hodge, D. R., \& Horvath, V. E. (2011). Spiritual needs in health care settings: A qualitative meta-synthesis of clients' perspectives. In Social Work (Vol. 56, Issue 4, pp. 306316). Oxford University Press. https://doi.org/10.1093/sw/56.4.306

Kozier B, Erb G, Berman, S. S. (2004). Fundamental Of Nursing: Concept, Process dan practice. 7th ed. Perarson Education.

Kristen, A., Lars, J., Kari, K., \& Venke, S. (2014). The power of consoling presence-hospicenurses' lived experience with spiritual and existential care for the dying. $B M C$ NursingMC, 13(25), 1-8. http://www.biomedcentral.com/14726955/13/25

Kumajas, Fisella, W., Warouw, H., \& Bawotong, J. (2014). Hubungan karakteristik individu dengan kinerja perawat di ruang rawat inap penyakit dalam RSUD Datoe Binangkang Kabupaten Bolaang Mongondow. Jurnal Keperawatan, Vol 2(2), 1-8. https://ejournal.unsrat.ac.id/index.ph p/jkp/article/view/5304

Laili, N. R., Zulkarnain, H., Yasmara, D., \& Sriyono. (2019). Promoting spiritual nursing care in an intensive care unit: A systematic review. Indian Journal of Public Health Research and Development, 10(8), 2773-2777.

https://doi.org/10.5958/09765506.2019.02291.5

Makmun, M., Sulung Utami, R., Keperawatan, M. (2019). Persepsi keluarga terhadap partisipasi keluarga dalam merawat pasien di ruang ICU: studi kualitatif. Jurnal Perawat Indonesia, 3(2). https://doi.org/10.1164/ccm

Nurhanif., Purnawan, I., \& Sobihin. (2020). Gambaran Peran Perawat terhadap Pemenuhan Kebutuhan Spiritual Pasien di Ruang ICU. Jurnal of Bionursing, 2(1), 39-46.

Perry \& Potter. (2012). Buku Ajar Fundamental Keperawatan. EGC.

Romadhoni. (2013). Pemenuhan kebutuhan spiritual oleh perawat di Ruang General Intensive Care Unit RSUP Dr. Hasan Sadikin Bandung 
[Universitas Padjajaran]. https://repository.unpad.ac.id/

Susilawati, D. (2014a). Hubungan antara dukungan keluarga dengan tingkat kecemasan penderita kanker serviks paliatif (The Correlation between Family Support with The Level of Anxiety of Patients with Palliative Cervical Cancer) Vol. 5, (1). http://ejournal.umm.ac.id/index. $\mathrm{php} /$ keperawatan/issue/view/226/sho wToc

Susilawati, D. (2014b). Hubungan antara dukungan keluarga dengan tingkat kecemasan penderita kanker serviks paliatif di RSUP Dr Sardjito Yogyakarta. Jurnal Keperawatan, 4, 1-15.

http://ejournal.umm.ac.id/index.php/ keperawatan/article/view/2358\%0Ak anker

Wardhani, D. P. (2017). Pengalaman perawat dalam pemenuhan kebutuhan spiritual islam pada pasien di Intensive Care Unit (ICU). Universitas Diponegoro. 